\title{
New record of Insuetophrynus acarpicus Barrio, 1970 (Anura: Rhinodermatidae) in Chile: implications for its conservation
}

\author{
Bernardo Segura Silva \\ Flora \& Fauna Chile Ltda. Magnere 1540 Of. 506. Providencia, Santiago, Chile \\ E-mail: bernardo.segura86@gmail.com
}

\begin{abstract}
A new record of the Critically frog Insuetophrynus acarpicus was discovered in Chile from a site lying 66 $\mathrm{km}$ southwest from the southernmost locality reported for the species. This new population is the first occurrence of the species in a protected area, and considerably extends the geographical and altitudinal range of I. acarpicus, one of the most endangered frogs in the world.
\end{abstract}

Key words: geographic distribution; threatened species; habitat fragmentation

Insuetophrynus acarpicus Barrio, 1970 is an endemic Chilean frog that is considered as one of the most threatened species in the world. It is classified as Critically Endangered by the IUCN based on a restricted geographical distribution and a continuing decline in the extent and quality of its habitat (Veloso et al. 2010). This species ranks $24^{\text {th }}$ on the Edge of Existence catalog (http://www.edgeofexistence.org) of the most endangered and evolutionary distinct species.

Insuetophrynus acarpicus is a medium-sized, robust and predominantly aquatic frog, although adults and tadpoles are not good swimmers. During the day, they remain hidden under stones in areas with running water, and at night, they emerge and can be found on the stones in the stream or at the bank (BARRIO 1970; DíAZ et al. 1983; RABANAL \& NUÑEZ 2012).

The main threats to this species are its restricted geographic distribution and the habitat destruction resulting from logging and afforestation with pine plantations (Veloso et al. 2010). The documented geographical distribution of $I$. acarpicus has experienced changes over time: the species was only known from a single locality for more than 30 years (Mehuín), but recent discoveries by Soto et al. (2002) and RABANAL \& NUÑEZ (2012) reported three additional populations: Queule north of Mehuín, Colegual Alto northeast of Mehuín, and Chanchán to the south. These three records expanded the geographical range of the species approximately $3 \mathrm{~km}$ north and $21 \mathrm{~km}$ south of Mehuín. Considering those new localities, the distance from the northernmost (Queule and Colegual Alto) to the southernmost population (Chanchán) recorded to date is only about $25 \mathrm{~km}$ (Table 1). Herein, I further extend the distribution of this Critically Endangered amphibian to Alerce Costero National Park. This new record of I. acarpicus is the first from a protected area and also represents the highest occurrence record for the species.

During a night field survey conducted between 8 and 14 February 2016, at Alerce Costero National Park (40 $11^{\prime}$ S, $073^{\circ} 27^{\prime} \mathrm{W} ; 700 \mathrm{~m}$ above sea level), a recently created National Park in Los Ríos region and La Unión and Corral communes, located $44 \mathrm{~km}$ southwest of Valdivia, and $66 \mathrm{~km}$ southwest of Chanchán (Figure 1), three adult individuals of I. acarpicus were observed (Figure 2). They were under semi-submerged rocks with their heads above water, but rapidly hiding under the rocks when approached. No tadpoles were found.

Insuetophrynus acarpicus is a conspicuous species from a monotypic genus. It is considered Critically Endangered according to IUCN criteria (VeLOSO et al. 2010). No individuals were collected and the record was made based on detailed photographs of an individual, in which some of morphological diagnostic features of the species could be observed (Figure 2).

Morphological and coloration features that diagnose I. acarpicus include the cornification on finger I and pectoral plates in adult males and females, prominent eyes with horizontal pupil, a dark stripe from nares to anterior margin of the eyes (canthal stripe), and abdominal region pink or whitish (Figure 2) (BARRIO 1970; DiAZ et al. 1983; Rabanal \& Nuñez 2009).

Other species found in the same habitat include Alsodes valdiviensis (Formas, Cuevas \& Brieva, 2002), Batrachyla antartandica (Barrio, 1967), Batrachyla leptopus (Bell, 1843), Eupsophus calcaratus (Günther, 1881), Eupsophus vertebralis (Grandison, 1961), Telmatobufo australis (Formas, 1972) and Rhinoderma darwinii (Duméril \& Bibron, 1841): all of them greatly differ in morphology compared to I. acarpicus (Figure 3).

The identification was made in situ by the author, and later confirmed by the specialist Felipe Rabanal (RABANAL 


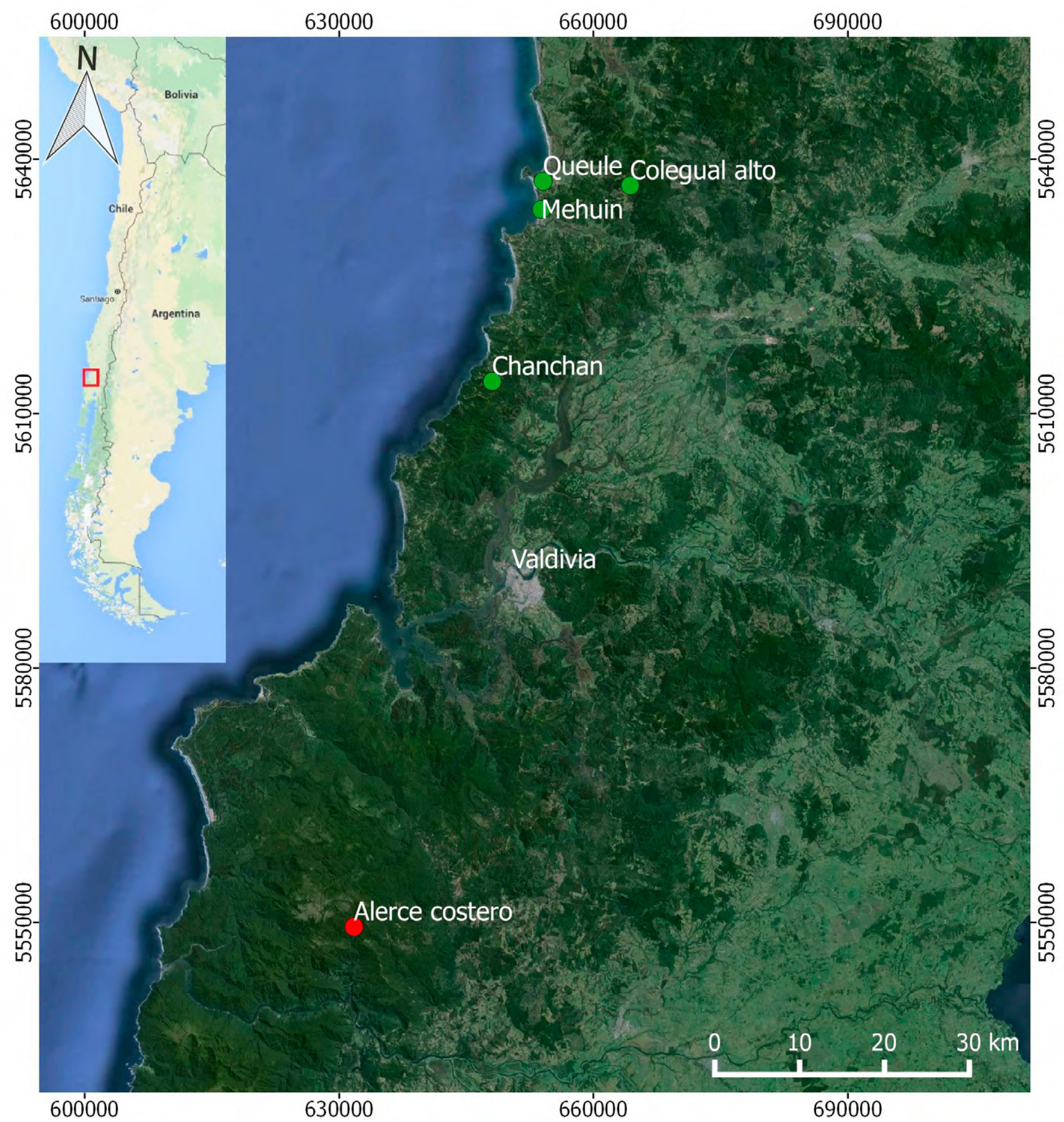

Figure 1. Distribution of Insuetophrynus acarpicus in Chile. Green circles: previously reported localities; red circle: newly discovered locality.

\& NuÑEZ 2009; RABANAL \& Formas 2009; RABANAL \& NuÑEZ 2012).

The new record is an important find as it extends the geographical distribution of the species $66 \mathrm{~km}$ southwest, the farthest known record for the species from its type locality. This discovery also extends the altitudinal range of occurrence for the species: from $486 \mathrm{~m}$ above sea level in Chanchán to $700 \mathrm{~m}$ at Alerce Costero National Park (Table 1).

The new record of Insuetophrynus acarpicus was found at a newly created National Park. Yet, the area where the species occurs is near a path that was recently opened to the public. According to park rangers, since its opening, crowds of people use this trail and bathe in the stream using soap and other chemical compounds that could be a threat to the frogs and tadpoles dwelling there. Thus, although this population is located inside a protected area, the park protects the forest from more evident impacts, such as deforestation, but also attracts visitors that can lead to an alteration of water quality in the stream where the species inhabits.

The justification for this species to be categorized as Critically Endangered according to IUCN criteria is its small geographical distribution and the continuing decline 


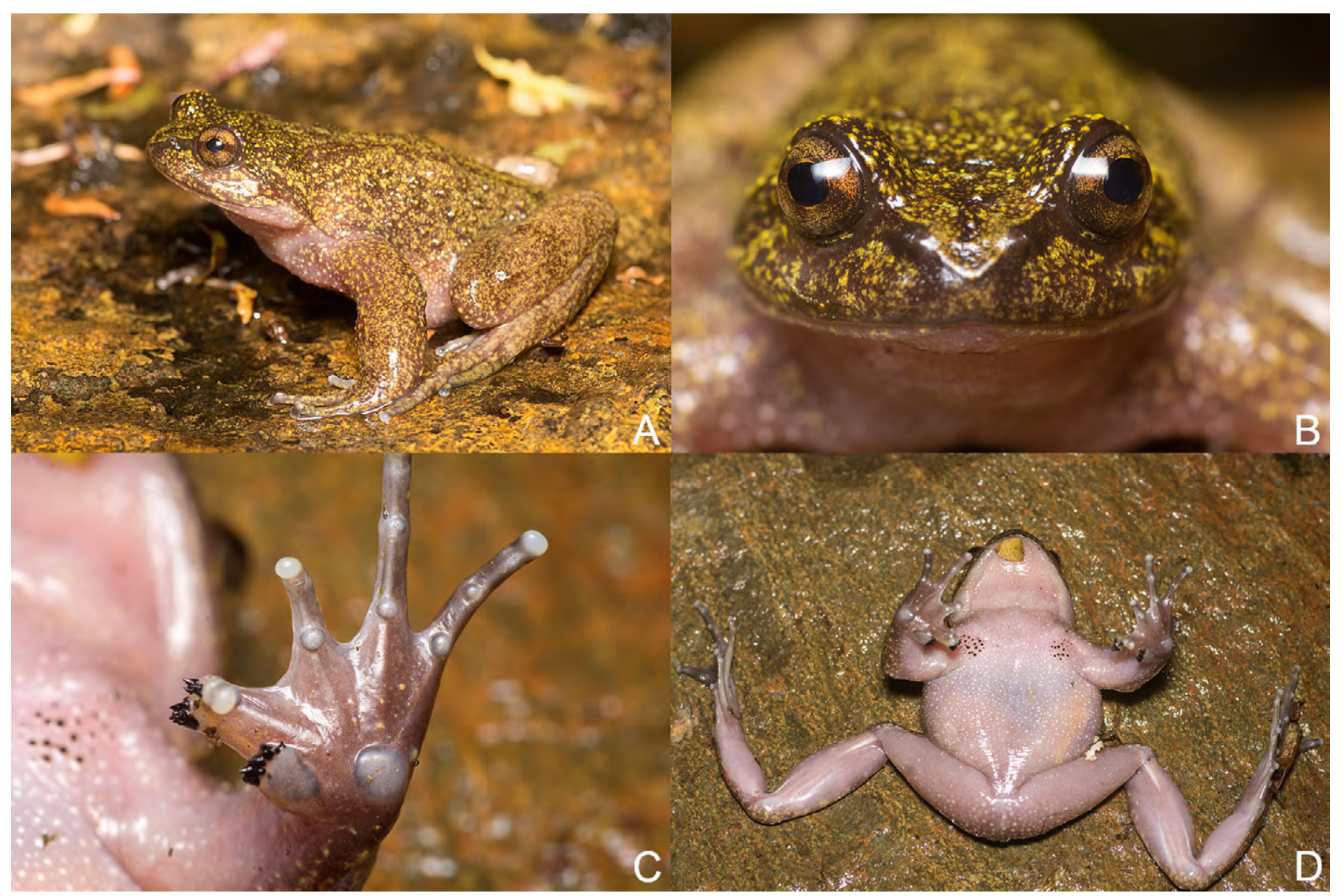

Figure 2. An adult male of Insuetophrynus acarpicus from the newly discovered population (Alerce costero, Chile) and its key features for the species identification. A. Individual in profile showing the horizontal pupil. B. Frontal view showing the dark-colored canthal stripe. C. Detail of the palm of hand showing the cornification on finger I and base of the hand. D. Individual in ventral view showing pectoral plates.

Table 1. Recorded localities of Insuetophrynus acarpicus in Chile from the literature.

\begin{tabular}{lccl}
\hline Locality & Geographic Coordinates & Altitude (m a.s.l.) & Reference \\
\hline Queule & $39^{\circ} 38^{\prime} \mathrm{S}, 073^{\circ} 14^{\prime} \mathrm{W}$ & 124 & SOTO et al. (2002) \\
Colegual Alto & $39^{\circ} 24^{\prime} \mathrm{S}, 073^{\circ} 06^{\prime} \mathrm{W}$ & 500 & SOTO et al. (2002) \\
Mehuín & $39^{\circ} 26^{\prime} \mathrm{S}, 073^{\circ} 13^{\prime} \mathrm{W}$ & $80-90$ & MÉNDEZ et al. 2006; RABANAL \& NUÑEZ (2012) \\
Chanchan & $39^{\circ} 36^{\prime} \mathrm{S}, 073^{\circ} 16^{\prime} \mathrm{W}$ & 486 & RABANAL \& NUÑEZ (2012) \\
Alerce Costero & $40^{\circ} 11^{\prime} \mathrm{S}, 073^{\circ} 27^{\prime} \mathrm{W}$ & 700 & This report \\
\hline
\end{tabular}

in the extent and quality of its habitat (VeLOso et al. 2010). With the range of this species now expanded to include an occurrence record inside a national protected area, the conservation status of Insuetophrynus acarpicus should be reevaluated.

There is a continuous, preserved forest that extends for about $100 \mathrm{~km}$ south of this record. This region has not yet been extensively sampled, so conducting surveys throughout this forest might be an important to better understand the distribution range of this endangered species in Chile.

\section{ACKNOWLEDGEMENTS}

I thank Felipe Rabanal for confirming the identification of the species and the useful comments on an early version of the manuscript, as well as two anonymous reviewers and the academic editor (Thiago R. de Carvalho), who greatly helped to improve this work. I also thank Sean Sultaire and Jannika Boström for helping with the translation. Finally, I would like to thank Javiera Zúñiga for its essential support on the fieldwork.

\section{LITERATURE CITED}

BARRIO, A. 1970. Insuetophrynus acarpicus, un nuevo leptodactílido firmisternio sudamericano (Amphibia: Anura). Physis 30: 331-341.

Díaz, N.F., J. VAlencia \& M. Sallaberry. 1983. Life history and phylogenetic relationships of Insuetophrynus acarpicus (Anura: Leptodactylidae). Copeia 1983(1): 30-37. http://www.jstor.org/ stable/1444695

Méndez, M.A., F. Torres-Pérez, C. Correa, E.R. Soto, J.J. Nuñez, et al. 2006. Genetic divergence in the endangered frog Insuetophrynus acarpicus (Anura: Leptodactylidae). Herpetological Journal 16: 93-96. 


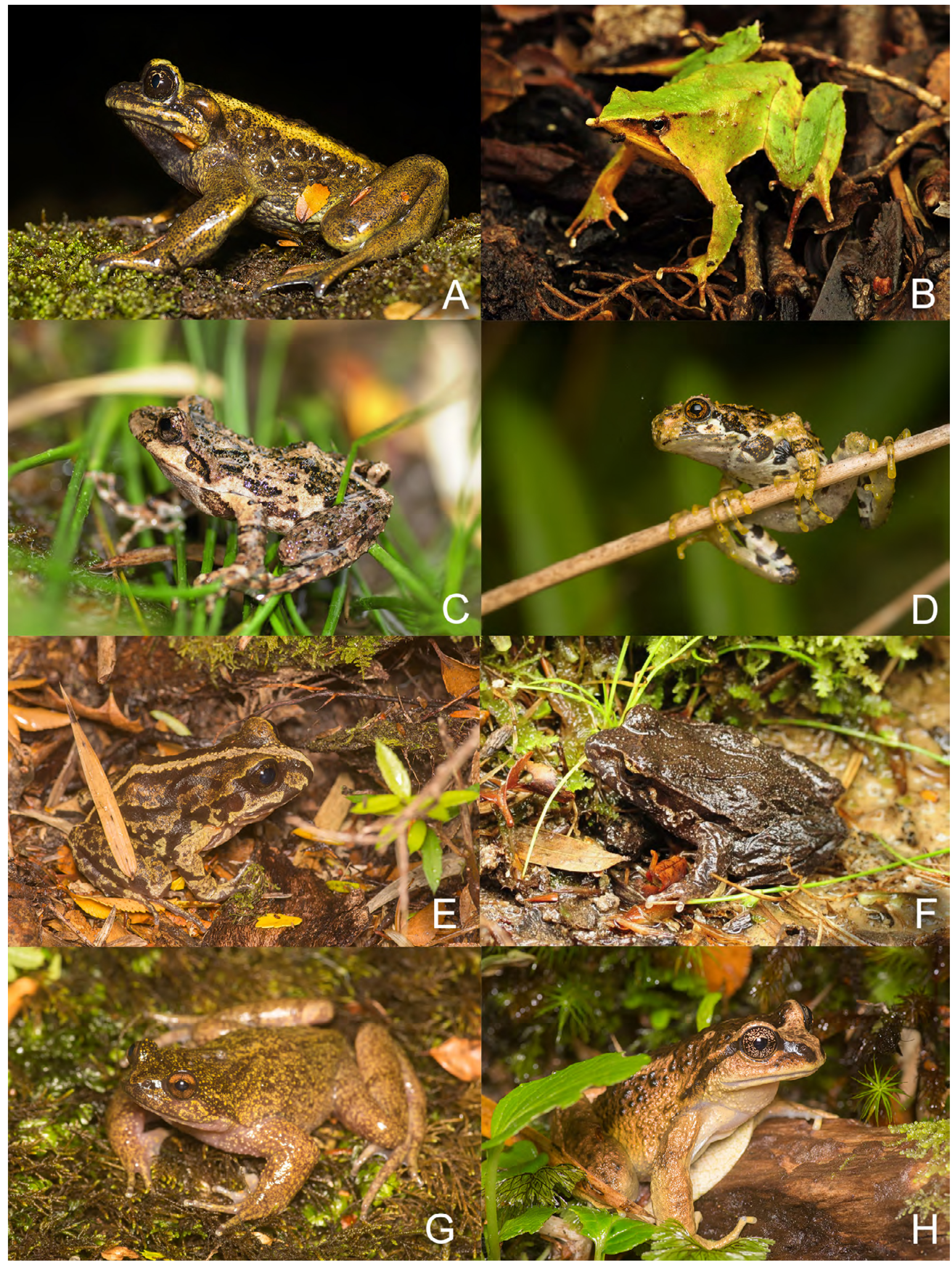

Figure 3. Sympatric amphibian species present at the study site. A. Telmatobufo australis. B. Rhinoderma darwinii. C. Batrachyla leptopus. D. Batrachyla antartandica. E. Eupsophus vertebralis. F. Eupsophus calcaratus. G. Insuetophrynus acarpicus. H. Alsodes valdiviensis. 
RABAnAL, F.E. \& J.J. NuñEz. 2009. Anfibios de los Bosques Templados de Chile. Valdivia: Universidad Austral de Chile. 206 pp.

RABANAL, F.E. \& J.R. Formas. 2009. Complementary diagnosis of the genus Insuetophrynus (Anura, Cycloramphidae) based on larval characters. Zootaxa 2116: 59-67.

RABANAL, F.E. \& J.J. NUÑEZ. 2012. Discovery of a new population of the Critically Endangered frog Insuetophrynus acarpicus Barrio, 1970 (Anura: Cycloramphidae): latitudinal and altitudinal extension in the Valdivian coastal range, southern Chile. Check List 8(4): 810-812. doi: 10.15560/8.4.810
Soto, E.R., M.A. Méndez-Torres, F. Torres-Pérez \& H. IbarraVIDAL. 2002. New localities of Insuetophrynus acarpicus. Herpetological Review 33: 317.

Veloso A, H. NÚÑEZ, J. NÚÑEZ \& R. Formas. 2010. Insuetophrynus acarpicus. The IUCN Red List of threatened species 2010. Accessed at http://www.iucnredlist.org, 19 February 2016.

Received: 18 March 2016

Accepted: 29 November 2016

Academic editor: Thiago Ribeiro de Carvalho 